\title{
Urban and rural dimensions in post-disaster adjustment challenges in selected communities in Kwara State, Nigeria
}

Raheem Usman Adebimpe

Department of Geography, Faculty of Business and Social Sciences,

University of Ilorin, Ilorin - Nigeria adebimpeusman@yahoo.com

\section{ABSTRACT}

Human populations are exposed to climate change directly through changing weather patterns as manifested in the more frequent extreme events and indirectly through changes in ecosystem functions. Rainstorm disasters are common events associated with environmental change and settlements in Kwara state, Nigeria were ravaged by rainstorm events between 2003 and 2006. More than 1000 households were displaced from their habitual homes with consequences for human health and other adjustment challenges. This paper examines the variations in the post-disaster adjustment challenges of rural and urban households so as to identify location specific intervention strategies in the domains of environment and health of the victims. A sample of 200 households was drawn from all households affected by rainstorm disaster as reflected in the FEMA records during the period. A structured questionnaire was administered in addition to the secondary data and analyzed using relevant statistical techniques. The findings include that most households required support before replacing the roofs and/or walls of their homes. Sources of support however vary. Urban households received more institutional support but lower than the amount required for the renovation. A significant proportion of urban households moved to poorer homes where they faced challenges relating to the quality of environmental services. Many urban respondents also reported increases in the occurrence of water-borne and weather-related diseases and ailments. Rural households indicated no significant ecological differences between their former homes and the areas to which they relocated. The paper concludes that significant variations exist in the adjustment challenges faced by rural and urban dwellers after a disaster. Community efforts hold promise for emergency response particularly during disasters in rural areas.

\section{KEYWORDS}

Disasters, Urban, Rural, Adjustment, Kwara, Nigeria

\section{Introduction and background to the study}

The magnitude of vulnerability to hazards and disasters varies in terms of geographical location, seasonality and exposure of population and infrastructure. Other factors include economic and social conditions, natural resource capital, political and institutional mechanisms, equity in terms of resource distribution and gender, and coping and adaptive capacity. 
Socio-cultural and economic factors play a key role in the vulnerability of certain groups to disasters (ICIMOD, 2009). These factors can also have a marked impact on the success or failure of risk reduction strategies in communities. This is because they often influence the readiness to adopt, modify or reject safety measures offered through outside assistance like governments or NGOs. Post-disaster adjustment, like vulnerability, is determined by a range of factors, including the extent of unplanned urbanization, the nature of physical assets and economic activities, and the state of the environment. Recognition of the role of socio-economic factors is important and underlines the fact that technical solutions are necessary but not sufficient.

It must be noted that the poverty-exacerbating nature of disaster vulnerability can be attributable to post-disaster related damage such as temporary loss of income-generating opportunities and increased indebtedness which is also related to deliberate risk-averting livelihood choices that poorer households may make. These choices can also vary between urban and rural areas affected by disasters. Thus, poor and disadvantaged groups can become differentially vulnerable through the differential impacts of the breakdown of traditional familial support, declines in traditional coping measures, and increased occupation of more dangerous land. Without careful attention to needs assessment and design of response strategies between urban and rural communities, increased provision of infrastructure and services can indeed increase disaster vulnerability.

In recent decades there has been an escalation in the incidence of severe disaster events in both the developed and developing worlds which is also believed to be increasing the frequency and severity of droughts, floods and cyclones. This has been in part due to a rise in vulnerability. The increased incidence of major disasters and the associated rise in the cost of post-disaster reconstruction efforts are increasingly recognized as a potential threat to both sustainable development and poverty reduction initiatives. Thus there is a need to understand how the responses of victims of disaster in rural and urban areas differ so as to know how policies can be made better able to address the challenges in the two spatial scales without violating the equity and justice principles.

The understanding of the rural and urban circumstances of victims of disaster can aid the understanding of the speed of recovery and the severity of impact. This paper investigates the similarities and differences in how floods and rainstorms affect urban and rural dwellers in selected communities of Kwara state, Nigeria. Pursuant to this broad aim, the study proceeds to answer the question of what differences and similarities exist in the socio-economic, health, environmental and psychological challenges faced by the victims. It also examines the differences in the nature of support they received in periods after the disaster. The significance of this study is that since, in most cases, flood and rainstorm events serve to weaken the economic status of households, an understanding of the various dimensions of adjustment between rural/ urban, men/women as well as between the rich and poor will assist in the recognition of the importance of mainstreaming disaster risk reduction in development planning and resource allocation at the local and national levels. 


\section{Disaster and vulnerability: Some conceptual issues}

According to Jigyasu (2002), vulnerability is a set of negative conditions within a community, which may be a consequence of several factors. This may be due to inherent weaknesses of these communities or be a consequence of external threats. On the other hand, local knowledge is a determinant of the capacity for reducing vulnerability and is thus a measure of positive conditions in a community. There is therefore an intricate link between the trio of vulnerability, local knowledge and capacities within a society. This is such that disaster vulnerability is both the cause and effect of degenerating local knowledge and capacities and of conditions of poverty. Disaster vulnerability possesses great conceptual complexity. For instance it can encompass various aspects of human sub-systems - physical, social, attitudinal, economic etc. It may hold true with respect to one hazard or multiple hazards, the whole community or a part thereof. Thus vulnerability is dynamic and does not remain the same for all people or communities over a long period of time. For instance, the kinds of vulnerability before a disaster may be aggravated by a disaster event whereas certain reactive actions (as relief and rehabilitation processes) may help in eradicating or reducing certain kinds of vulnerabilities, changing certain vulnerabilities to different kinds and reinforcing or compounding or strengthening or even increasing others. The vulnerability conditions can also change with time on their own through certain inherent community coping mechanisms or other practices (ICIMOD, 2009).

Vulnerability to natural disasters can therefore be understood as 'products and 'processes', existing before as well as after a disaster (Jigyasu, 2002). Disaster vulnerability is therefore not only a pre-disaster phenomenon but also a product of external human interventions and myths or perceptions of decision makers, undertaken as post-disaster decisions or actions. The guiding thesis in this paper is that disaster is a continuous event which only manifests during and after the occurrence of a hazard. The access model (Figure 1) by Blaikie et al. (1994) is used to illustrate the pre- and post-disaster challenges and the nexus between social, political and economic contexts in the recovery process.

Figure 1: Vulnerability and capacity as dynamic process

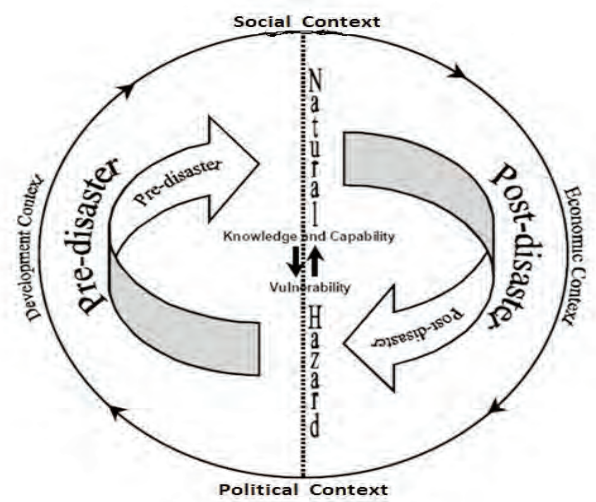

Source: Blaikie et al., 1994, cited in Jigyasu, 2005 
Figure 1 reflects a simple model of the processes by which the underlying factors and root causes embedded in everyday life give rise to dynamic pressures affecting particular groups. This also creates a series of 'unsafe conditions' for the functioning of human systems. The model essentially demonstrates that vulnerability is generated by the interactions of political and economic processes or circumstances of people. Although Jigyasu (2005) had criticized the linear conception of the model, it is believed that the ability of the model to demarcate between the pre- and post-disaster situations as well as the establishment of the interaction of the different contexts of disaster victims in the process of recovery is a strength. Hazards in themselves do not constitute disasters. The magnitude of disaster is usually described in terms of the adverse effects which a disaster has had on lives, property and infrastructure; environmental damage; and the costs attached to post-disaster recovery and rehabilitation. Simply put, therefore, disaster risk is the product of the combination of three elements - vulnerability, coping capacity and hazard (UNDP, 2004). This interaction is illustrated in the following formula:

\section{Disaster risk $(\mathbf{R})=\underline{\text { Vulnerability }(\mathrm{V}) \times \operatorname{Hazard}(\mathrm{H})}$ \\ Capacity (C)}

Extreme natural phenomena do not in themselves constitute hazards. It is only when such phenomena occur in an environment where they pose a threat to human life, property, infrastructure or the environment that they can be classified as hazards. Similarly in the case of technological developments, hazards occur only when such developments pose a danger such as industrial accidents and infrastructure failures. In essence, a disaster is the result of a hazard's impact on society. So the effects of a disaster are determined by the extent of a community's vulnerability to the hazard.

Hazards are increasingly dynamic and have highly varying potential impacts. A wide range of geographical, meteorological, hydrological, environmental, technological, biological and sociopolitical hazards can threaten livelihoods and sustainable development. Hazards can be classified into three broad categories:

- Natural hazards

- Technological hazards

- Environmental degradation (Palm, 1990; cf. Hunter \& David, 2009).

It should be noted that all communities whether rural or urban are vulnerable to hazards. However, different regions will be more prone to certain types of hazards than others.

Natural hazards are those triggered by climatic and geographical variability, which is at least partly beyond the control of human activity (Palm, 1990). Technological hazards represent dangers originating from technological or industrial accidents, dangerous procedures, infrastructure failures or certain human activities which may cause a loss of life or injury, property damage, social and economic disruption or environmental degradation. Degradation of the environment is a process induced by human behaviour and activities (sometimes 
combined with natural hazards) that damage the natural resource base or adversely alter natural processes or ecosystems (Palm, 1990). Potential effects are varied and many contribute to an increase in vulnerability and the frequency and intensity of hazards. Accordingly, disaster risk reduction or management suggests a systematic process that integrates risk identification, mitigation and transfer, as well as disaster preparedness, emergency response and rehabilitation or reconstruction to lessen the impacts of hazards (Cardona, 2005).

One of the major factors affecting poverty reduction among the poor in African cities is perennial flooding. This also stands in the way of the United Nations 2020 goal of achieving significant improvement in the lives of urban slum dwellers (ActionAid, 2006). This, according to Adelekan (2009), is because many African cities lack the infrastructures to withstand extreme weather conditions. Poor urban planning together with other urban governance challenges contributes to making African urban slum dwellers most at risk. Poor urban planning or lack of planning as urban development increases is evident in not preventing new development on areas at risk of flooding, leaving unprotected areas that should be left undeveloped, for instance wetlands, because of their role as buffers against flooding risks and also not providing safer sites for the urban poor. McGranahan (2007) noted that while economic activity and urban development often increase the environmental pressures that lead to flooding, it is the low income settlements and poor groups within all settlements that tend to be the most vulnerable.

\section{Disasters occurrence in nigeria: An overview}

The available literature shows the existence of spatial differences in the nature of disasters experienced in Nigeria. While oil and gas pollution is largely a Niger Delta problem, drought and quella birds infestation occur in the Sudano-Sahelian states (e.g. Kano, Sokoto, Katsina, Borno and Yobe). These disasters have been accompanied by numerous casualties including property damage. In 2001, the communal conflict in Akampa Local Government Area in Cross River State led to the displacement of about 3,000 people and left 12 dead. The Tiv/ Hausa-Fulani clash in Nasarawa State culminated in the death of 50 persons and displacement of 50,000 people. Furthermore, during the same period the flood disasters in Aba, Kirfi (Bauchi State), Talata Mafara (Zamfara State) led to the dislocation of about 13,000 people although no casualties were recorded (Orebiyi, 2002). It is important to note that of all disasters, soil erosion, rainstorm and flood disasters are the most common as they are prevalent in virtually all states in the country. This explains the reason for the choice of rainstorm and flood disasters as the focus for this study.

For instance, studies of the hydrological changes associated with urbanization (Akintola, 1994) have described the contribution of topographic conditions, rainfall characteristics, land use changes (especially the expansion of paved impermeable areas), uncontrolled waste dumping and construction on the flood plain, to local flooding (Oriola, 1994; Babatolu, 1997). Olaniran and Babatolu (1996) also pointed to the roles of rainfall amount and intensity as contributing to the frequency of flood events in Nigeria.

The perception of, impacts of and adjustments to urban flooding in Nigeria have been studied in Ayoade and Akintola (1980), Muoghalu and Okonkwo (1998), French et al., (1994), and 
Ologunorisa (1999). The Nigerian coastal lowland cities of Lagos and Port Harcourt are particularly vulnerable to coastal flooding and flash flooding from heavy rains because parts of Lagos are two metres below sea level. Many slum dwellings are built on stilts over swamps and other wetlands. Blockage of channels by debris and obstruction of floodways by new construction were seen as the main obstacles contributing to the Port Harcourt flooding (Abam et al., 2000). Worsening urban flooding is affected by both global climate change and local changes to drainage systems and rivers. The local changes are due to construction, blockage of drains and increased local runoff from hard, paved and compacted surfaces. These local and global changes work together to increase flood frequency, magnitude and duration. The urban poor are suffering more than other urban residents from these changes. Public health has also suffered as flooding has increased the number of outbreaks of cholera, causing several deaths (ActionAid, 2008).

\section{Figure 2. During a flood event in Ilorin Metropolis in 2008}

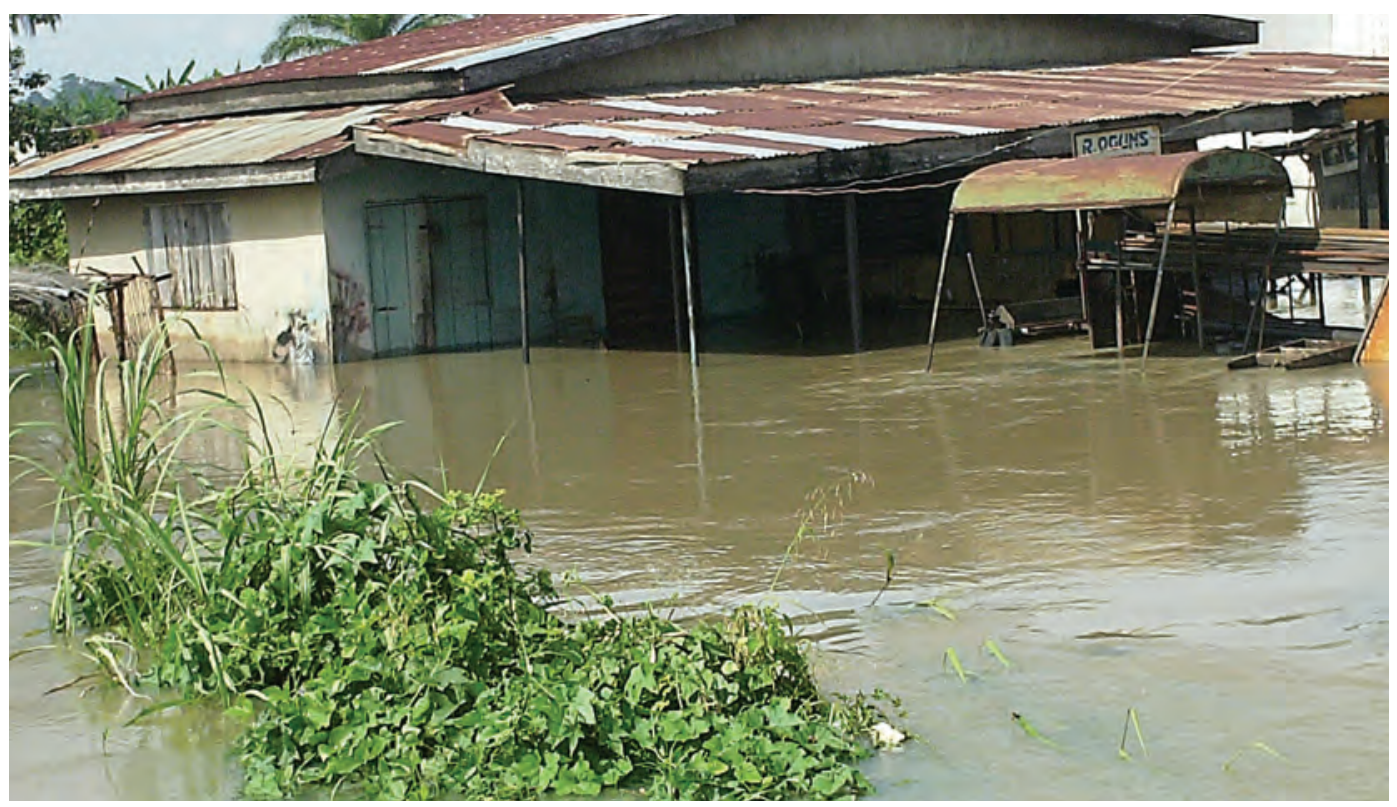

\section{Source: Photo by author, 2008}

In a nutshell, it is clear from the literature that climate change is altering rainfall patterns and tending to increase storm frequency and intensity, thus increasing the potential for floods. As a consequence, urban flooding is becoming an increasingly frequent and severe problem for the urban poor due to a host of local human factors, especially urban growth, occupation of flood plains and lack of attention to waste management and maintenance of drainage channels.

The small streams in urban areas thus rise quickly after heavy rain, but often have to pass through small culverts under roads. Poorly designed drainage channels produce more flows that exceed the capacity of the culverts. In lowland and coastal cities, wet season flooding may affect some areas for two or more months, because rain and river water combine to raise the 
levels of water in swamps which would have naturally been inundated at certain times of the year. Dumping of waste beneath dwellings in these areas tends to help raise levels further. Storm waves can also bring flooding to such areas.

\section{Kwara State: Some geographical background}

The focus of this study is Kwara State in Nigeria. The State was created in May 1967 and occupies a geographically advantaged position on the map of Nigeria. It is located between Latitudes $11^{\circ} 2^{\prime}$ and $11^{\circ} 45^{\prime} \mathrm{N}$ and between Longitude $2^{\circ} 45^{\prime}$ and $6^{\circ} 4^{\prime} \mathrm{E}$. It lies midway between the northern and southern parts of Nigeria bounded in the north by Niger State and shares an international boundary with the Republic of Benin in the west. To its eastern border is Kogi State; while in the south it shares a boundary with the four states of Ekiti, Ondo, Osun and Oyo. The location of the State within the Nigerian space is shown in Figure 2.

\section{Figure 2. During a flood event in Ilorin Metropolis in 2008}

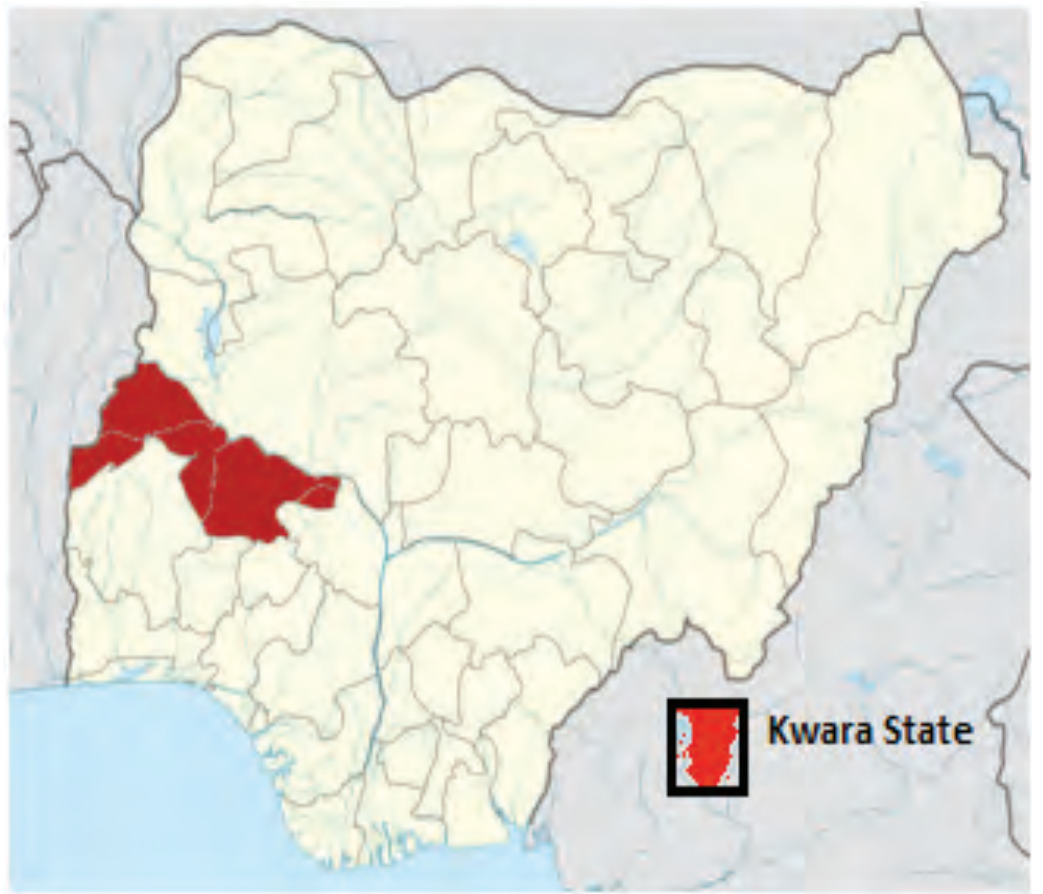

The State is covered by the Sudan and Woody Savanna vegetation with a mean annual rainfall and temperature of $1,338 \mathrm{~mm} / \mathrm{year}$ and $26.5^{\circ \mathrm{C}}$ respectively. Added to this is the availability of abundant natural resources. Kwara State is a transition state both physically and culturally. There are thus various cultures and a host of ethnic groups existing in perfect harmony in the State. However, the level of development showcased in the State appears to have betrayed the scenario described above as the State ranks among the least developed in Nigeria. The State is covered by the Sudan and Woody Savanna vegetation with a mean annual rainfall and temperature of $1,338 \mathrm{~mm} /$ year and $26.5^{\circ \mathrm{C}}$ respectively. Added to this is the availability of 
abundant natural resources. Kwara State is a transition state both physically and culturally. There are thus various cultures and a host of ethnic groups existing in perfect harmony in the State. However, the level of development showcased in the State appears to have betrayed the scenario described above as the State ranks among the least developed in Nigeria.

\section{Population: Distribution and characteristics}

The population of the State was about 1.5 million people in the year 2006 (Kwara State, 2010). The spatial distribution of the population of Kwara State is uneven. The State has a generally low density varying from as low as 8 persons per square kilometre in the north to 968 per square kilometre in the south. The cultural, religious and ethnic mix of the State is reflective of the uniqueness of its geographical location and history. The state's religious mix is a combination of Islam and Christianity, while the major ethnic groups are the Yoruba, Nupe and Baruba. The Yorubas are clearly in the majority but the nature of the relationship is such that a very high degree of integration and intermarriage exists among the different ethnic groups.

The gender distribution of the population shows that the figure is divided roughly equally between the two sexes. The female population constitutes about $50.4 \%$ or $1,139,718$ persons while the male represents $49.6 \%$ or $1,122,393$ persons. This sex distribution has an optimistic implication for fertility and hence population increase.

About $52 \%$ of the population of Kwara State is in the adult category while $48 \%$ are children and youths below the age of 18 years. This means that the structure of the State's population is generally youthful with a high ratio of dependency. This dependency characteristic has great consequences for human wellbeing in particular and economic development of the State in general. This therefore underlines the need for effective planning for rapid economic transformation in the State.

\section{Methodology}

\section{Data collection}

The data for this study were obtained from both primary and secondary sources. The primary data were extracted from a structured questionnaire administered to two hundred heads of households sampled from the victims of rainstorm disasters in Kwara State between 2003 and 2006. This represents about $20 \%$ of the 1061 households affected by rainstorm and/or flood events recorded by the Kwara State Office of the Federal Emergency Management Agency (FEMA). The records of FEMA included the names of house owners and the location addresses of the houses. It was therefore possible to categorize victims according to their locations. The samples were drawn from ten communities purposively sampled to include five each of rural settlements and urban neighbourhoods. Using the table of random numbers, the rural settlements included in the sample are Lanwa, Oke-Oyi, Oko-Olowo, Egbejila and EiyeNkorin. Samples were also drawn from Edun, Pakata, Okelele, Niger Road, and Adangba within the Ilorin metropolis. In each settlement and neighbourhood, twenty households were sampled randomly from the FEMA list and followed up to their location for an interview using 
a structured questionnaire. In the event of non-response by the selected household, another household was immediately selected to complete the required sample. The questions were drawn to reflect the socio-economic and demographic backgrounds of rainstorm victims as well as the challenges they face in the periods immediately following the disaster events that affected them. In each case the head of household was the target respondent or any member of the household that was 18 years or over who volunteered to grant the interview.

The secondary data include the recorded victims of flood and rainstorm events between 2003 and 2006 and were obtained from the Kwara State Office of the Federal Emergency Management Agency (FEMA). The agency compiled records of victims in fairly adequate format which enabled the researcher to trace locations of victims, identify the nature of damage and the relief materials that were provided by government. The population and household characteristics in the State were compiled from the National and State population and housing tables (Priority Tables Volume 1) of the National Population Commission (NPC, 2009).

\section{Data analyses}

The data obtained through the procedures described above were analysed using simple nonparametric statistics. The method of Chi-Square $\left(\mathrm{X}^{2}\right)$ was used to establish the nature of variation that existed in the challenges faced by victims and whether post-disaster challenges and adaptation varied significantly between rural settlements and urban neighbourhoods. In most parts, the reports from the five sampled rural settlements were discussed together under the heading 'rural' while those of the five urban neighbourhoods were aggregated as the 'urban'. The findings from these analyses are reported in the sections that follow.

\section{Analyses and findings}

\section{Socio-economic characteristics of respondents}

Table 1 shows the summary of the socio-economic characteristics of sampled victims of flood and/or rainstorm events in Kwara State. According to the Table, about $80 \%$ of the sampled households were headed by men while the remaining $20 \%$ were female-headed households. More than $70 \%$ of the household heads were older than 30 years. It is striking to note that $22 \%$ of the household heads were single. These were households where the eldest son stood in for the head in his absence or where the male head was dead and his eldest child assumed headship. Apart from this category of households, other household heads were either married (51.5\%) or were among others divorced, separated, and widowed (17.5\%). Thirty-one percent and $29 \%$ of victims of rural and urban areas respectively had no formal education of any kind while the remaining had at least primary education. In the rural areas, 53\% of the heads of households that were affected were farmers, while 32\% were artisans. In the city, 26 and 29 percent respectively were civil servants and artisans.

Household sizes were larger among the victims of rainstorm and flooding events in rural areas than in the city. For instance more than $60 \%$ of the households sampled in the rural communities had more than six members, while only $38 \%$ of the sampled households in the urban 


\section{Raheem Usman Adebimpe}

neighbourhoods had more than six members. Finally, income levels were generally low, and up to $65 \%$ of heads of households in rural communities and $22 \%$ of heads of households in urban neighbourhoods earned between N5,000-N10,000 (\$33-\$68) per month.

It is important to note that the socio-economic characteristics of heads of households have farreaching implications for the adequacy, timeliness and appropriateness of the households response to various challenges faced during and after extreme meteorological events.

Table 1. Socio-economic characteristics of flood/rainstorm victims in Kwara State, Nigeria

\begin{tabular}{|c|c|c|c|c|}
\hline \multicolumn{2}{|c|}{ Socio-economic Characteristics } & \multirow{2}{*}{$\begin{array}{c}\text { Rural } \\
86\end{array}$} & \multirow{2}{*}{$\begin{array}{c}\text { Urban } \\
73\end{array}$} & \multirow{2}{*}{\begin{tabular}{c|} 
Total \\
159
\end{tabular}} \\
\hline Sex & Male. & & & \\
\hline & Female & 14 & 27 & 41 \\
\hline & & 100 & 100 & 200 \\
\hline \multirow[t]{7}{*}{ Age } & 20 and below & 15 & 3 & 18 \\
\hline & $21-30$ & 20 & 17 & 37 \\
\hline & $31-40$ & 24 & 28 & 52 \\
\hline & $41-50$ & 18 & 32 & 50 \\
\hline & $51-60$ & 10 & 12 & 22 \\
\hline & 61 yrs \& Above & 13 & 8 & 21 \\
\hline & & 100 & 100 & 200 \\
\hline \multirow[t]{4}{*}{ Marital status } & Single & 16 & 28 & 44 \\
\hline & Married & 68 & 53 & 121 \\
\hline & Others & 16 & 19 & 35 \\
\hline & & 100 & 100 & 200 \\
\hline \multirow[t]{5}{*}{ Education } & No formal education & 31 & 29 & 60 \\
\hline & Primary & 36 & 33 & 69 \\
\hline & Secondary & 21 & 23 & 44 \\
\hline & Tertiary & 12 & 15 & 27 \\
\hline & & 100 & 100 & 200 \\
\hline \multirow[t]{5}{*}{ Occupation } & Farming/Trading & 38 & 11 & 49 \\
\hline & Civil servants & 21 & 26 & 47 \\
\hline & Artisans & 32 & 29 & 61 \\
\hline & Unemployed/retired & 9 & 34 & 43 \\
\hline & & 100 & 100 & 200 \\
\hline \multirow[t]{5}{*}{ Household size } & $1-3$ & 8 & 21 & 29 \\
\hline & $4-6$ & 31 & 41 & 72 \\
\hline & $7-10$ & 45 & 25 & 70 \\
\hline & 10 and above & 16 & 13 & 29 \\
\hline & & 100 & 100 & 200 \\
\hline Income Level & Below N5,000 & 27 & 6 & 33 \\
\hline \multirow[t]{5}{*}{ (Average monthly) } & $\mathrm{N} 5,000-\mathrm{N} 10,000$ & 39 & 16 & 55 \\
\hline & $\mathrm{N} 10,000-\mathrm{N} 15,000$ & 16 & 35 & 51 \\
\hline & $\mathrm{N} 15,000-\mathrm{N} 20,000$ & 11 & 17 & 28 \\
\hline & $\mathrm{N} 20,000$ and above & 7 & 26 & 33 \\
\hline & & 100 & 100 & 200 \\
\hline
\end{tabular}




\section{Post-disaster challenges in urban and rural areas: are there significant differences?}

The challenges faced by victims of floods and rainstorms were categorised into five categories; namely socio-economic, health, environmental, psychological and the nature of support victims received after the events. These categories were drawn up from the summary of responses in the survey and formed the major challenges identified by the respondents. Table 2 shows the distribution of respondents on the basis of the challenges that they faced in the period immediately after the rainstorms and/or flood disasters that affected their homes. It is important to note that some of the households indicated that they faced more than one challenge under each category, while some households did not indicate any notable challenge in some of the categories used in this survey. This may explain why the responses received in Table 2 may be greater or lower than the total sample for the study.

Table 2. Post-disaster challenges in rural and urban areas of Kwara State, Nigeria

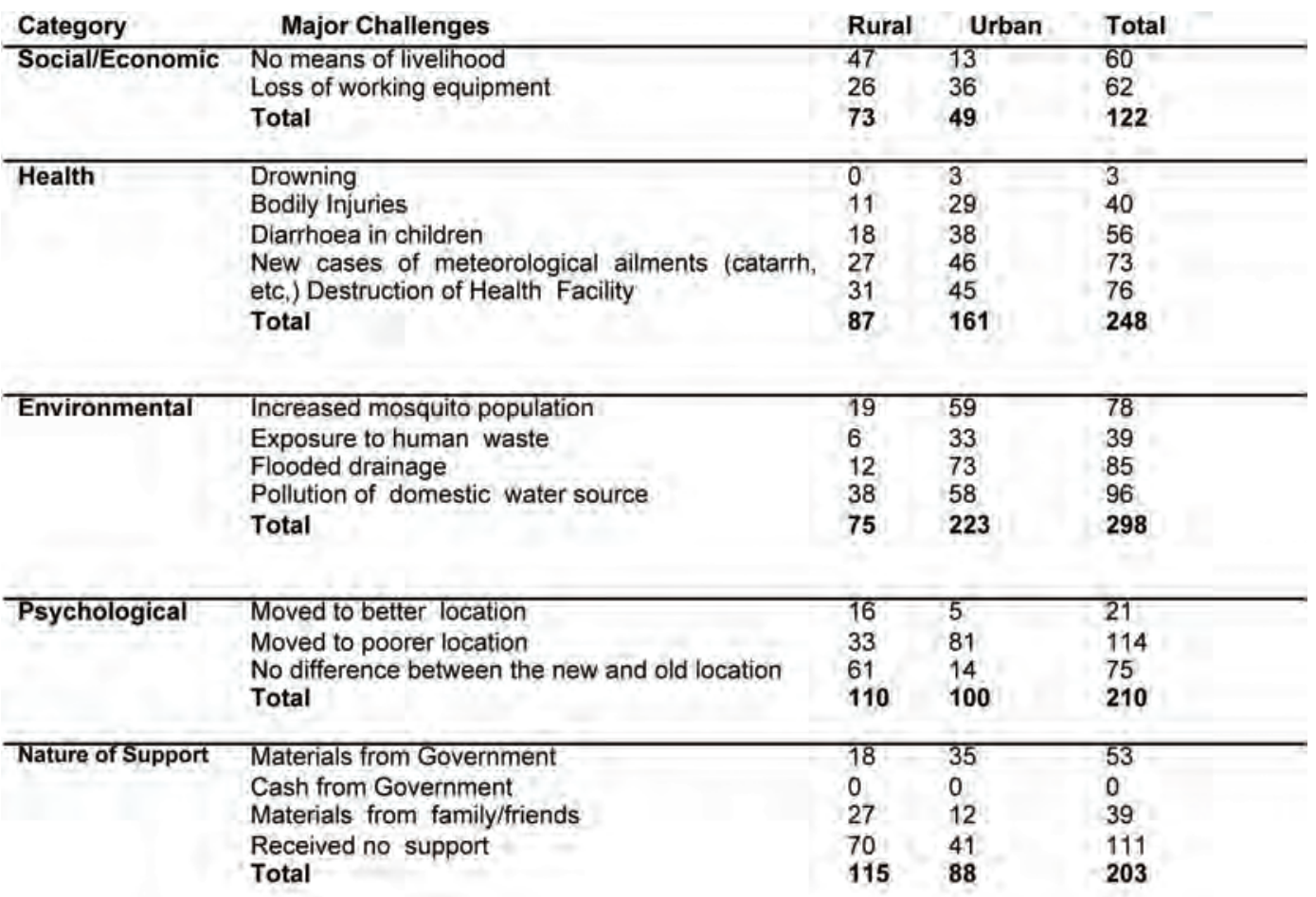

Source: Author's survey, 2009

As the Table shows, about $61 \%$ of the sampled households in both rural and urban areas indicated that the rainstorm/flood events that affected their houses also devastated their livelihood systems. This includes loss of farmland to flooding and collapse of business premises.

Moreover, about $20 \%$ of the total respondents suffered bodily injuries while diarrhoeal cases were reported in $28 \%$ of the sampled households. By far the commonest health related challenge in both rural and urban areas was the increase in cases of meteorological-induced ailments like 
severe colds and pneumonia occurring in $31.5 \%$ of the sampled households, while health facilities near to $38 \%$ of the households were destroyed. In 78 households (39\%), the population of malarial causing anopheles mosquitoes increased, while at least $33 \%$ of the households sampled in the city and $6 \%$ in rural communities indicated they were exposed to human waste as a result of the flood. Pollution of the domestic water sources was therefore a major environmental challenge reported in about $48 \%$ of the households, while $43 \%$ of the households indicated that the drainage around their houses was flooded.

In all, there is a general variation in the proportion of households exposed to the various challenges after the extreme weather events that affected them. The object of this study is to analyze these post-disaster challenges with a view to determining if there are significant statistical variations between urban communities and rural areas so as to be able to identify specific challenges of each geographic area. To achieve these objectives, a chi-square analytical technique was adopted to examine the significance of the variations observed in Table 2 above. The result is shown in Table 3.

Table 3. $X^{2}$-analyses of the variation in post-disaster challenges in urban and rural areas of Kwara State, Nigeria

\begin{tabular}{|c|c|c|c|}
\hline \multirow{2}{*}{ Adjustment Challenges } & \multicolumn{2}{|c|}{$\mathbf{X}^{2}$-Results } & \multirow{2}{*}{$\begin{array}{c}\text { Decision on Null } \\
\text { Hypothesis }\end{array}$} \\
\cline { 2 - 3 } & Calculated value & Table Value & Rejected \\
\hline Socio-Economic & 30.62 & 11.07 & Rejected \\
\hline Health & 105.58 & 16.92 & Rejected \\
\hline Environmental & 18.51 & 14.87 & Rejected \\
\hline Psychological & 47.00 & 11.07 & Accepted \\
\hline Nature of Support & 5.62 & 11.67 & \\
\hline
\end{tabular}

Source: Author's computation, 2009

Ho: The variations observed in each of the post-disaster challenges among urban and rural households in Ilorin Metropolis are not statistically significant.

Decision Rule: Reject Ho if $X^{2}$-calculated is greater or equal to $X^{2}$-tabulated at $5 \%$ confidence level; accept Ho if the reverse is correct.

As shown in the Table above, the variations observed in the challenges to socio-economic life between urban and rural households were found to be statistically significant. This result conforms with the expectation that in rural areas, farm land distribution is scattered and an ample opportunity exists for farmers to farm in land parcels that are less susceptible to flooding or to relocate to other parcels when farms are affected by floods. On the other hand, houses are built close to each other in cities and in most cases, flood or rainstorm events easily become devastating and when these occur, opportunities are limited for the victims to relocate to other houses or business premises. This is worsened by the cost of acquiring new locations and the longer search time. 
Aside from this, the public health consequences of floods are greater in cities where flows from even 'normal rains' often carry along their path significant urban waste from various houses to the downstream areas. Thus the heavier the downpour, the greater the exposure to unprotected human wastes and dead animals washed from open pits, refuse dumps and open septic tanks. This is worse in the inner parts of the cities where houses are often built without toilets and bath-places. In such areas, flooded streets are aggravated by the existing poor sanitation and drainage systems.

In all, a significant difference is shown to exist in the psychological challenges suffered by victims of extreme weather events. These challenges include the need to relocate from their former residence to a poorer apartment or neighbourhood particularly in the city. Rural houses are relatively homogeneous; therefore victims of extreme events indicated that they did not feel much stress because their new location was not too different from the former. This is not the case in cities where houses are scarce and expensive. Thus the victims are often forced to settle in any available apartment or neighbourhood consequent upon the urgency and cost. Finally, this study found no significant variation in the nature of support received from government by victims of flood events in both rural and urban areas. Most of them claimed that the relief material came when they had borrowed or sold their properties to repair their houses after the disaster.

\section{Summary and conclusions}

This study investigates the differences and similarities that exist between flood and rainstorm victims in rural and urban communities of Kwara State, Nigeria. The study obtained data from a survey of flood and rainstorm victims selected from both rural communities and urban neighbourhoods in the State. The survey employed a structured questionnaire to elicit information on the challenges they faced in the periods immediately after the disaster. The study found significant statistical variations in post-disaster challenges faced by victims in the areas of health, environmental/ecological problems as well as in psychological challenges among rural and urban areas. On the other hand, the study found no significant statistical difference in the support received by both rural and urban victims.

The implications of these findings include the fact that the severity of the impact of floods and rainstorms varies between urban and rural areas. As the study shows, this variation may be related to the spatial structure of buildings and the generally low pressure on the ecological systems in rural areas. The opposite is the case in urban neighbourhoods where buildings are compact and place higher anthropogenic pressure on the urban ecological systems.

This calls to question the urban planning strategies by revealing the near absence of disaster preparedness mechanisms and systems. In most parts of the pre-colonial African cities, especially in the inner parts, housing and road constructions show a demonstrable inability of planners to envisage extremes of any 'normal' situation like traffic, population growth, rainfall, etc. thus a slight drift of any of these 'natural events' towards the extreme easily puts planning and policy out of their precarious balance. To worsen this, institutional responses are too politicised, irregular, meagre, untimely and of no effect in the context of the damages caused by the disaster. 
The solutions to these problems lie in a deliberate intervention in the development of the inner cities of pre-colonial African cities. This can take the advantage of urban renewal efforts in these parts by legislating on the minimum standard for houses. The existing legislation seems to isolate inner parts of the city and allow random development to occur. The municipal authorities responsible for city planning often abandon the inner parts of the city where planning laws and initiatives do not necessarily take effect. Overtime, these areas may become slums even when the outer parts of the city are well planned.

In addition, government must move to bridge the gap between the time of disaster and the time when victims receive the relief materials or funds. Moreover, as Costello et al.(2009) note, "Management of the health effects of climate change will require inputs from all sectors of government and civil society, collaboration between many academic disciplines, and new ways of international cooperation that have hitherto eluded us". Local communities must be involved in monitoring, discussing, advocating, and assisting with the process of adaptation particularly in the mitigation measures that directly concern them and innovative actions that are targeted at the local communities. Finally, as the study shows, disaster risk vulnerability and adjustment challenges among households are related to geographical scales as well as socio-economic characteristics; thus a sustainable intervention from governments and non-governmental institutions is the one that develops an integrated framework aimed at accommodating both geographical and socio-economic dimensions of vulnerability of households to disaster risks.

\section{References}

ABAM, T.K.S., OFOEGBU, C.O., OSADEBE, C.C. \& GOBO, A.E. 2000. Impact of hydrology on the Port-Harcourt-Patani-Warri Road. Environmental Geology, 40(1-2):153-162.

ACTIONAID. 2006. Climate change, urban flooding and the rights of the urban poor in Africa: key findings from six African cities. London: ActionAid. 7 p. Available at http://www.actionaid.org/docs/ urban\%20flooding\%20africa\%20report.pdf

ACTIONAID. 2008. Unjust waters: climate change, flooding and the protection of urban poor communities: experiences from six African cities. London: ActionAid. 24 p. Available at http://www. actionaid.org.uk/doc_lib/unjust_waters.pdf

ADELEKAN I.O. 2009. Vulnerability of poor urban coastal communities to climate change in Lagos, Nigeria. Paper read at the Fifth Urban Research Symposium held in Paris, France. Available at http://siteresources.worldbank.org/INTURBANDEVELOPMENT/

Resources/336387-1256566800920/6505269-1268260567624/Adelekan.pdf

AKINTOLA, F. 1994. Flooding phenomenon. (In Filani,M.O., Akintola, F. \& Ikporukpo, C.O., eds. Ibadan Region. Ibidan: Rex Charles Publication. p. 244-255.)

AYOADE, J. \& AKINTOLA, F. 1980. Flood perception in two Nigerian cities. Environment International, 4:227-280. 
BABATOLU, J. 1997. The June 24th 1995 flood in Ondo: its antecedents and incidents. Ife Research Publication in Geography, 6:158-164.

BLAIKIE, P., CANNON, T., DAVIS, I. \& WISNER, B. 1994. At risk: natural hazards, people’s vulnerability, and disasters. 1st ed. London: Routledge. 320 p.

CARDONA, O.D. 2005. Indicators of disaster risk and risk management: program for Latin America and the Caribbean: Summary Report. Washington: IADB. Available at http://idbdocs.iadb.org/wsdocs/getdocument.aspx?docnum $=1056825$

COSTEllO, A., ABBAS, M., ALLEN, A., BALL, S., BELL, S., BELLAMY, R., FRIEL, S., GROCE, N., JOHNSON, A., KETT, M., LEE, M., LEVY, C., MASLIN, M., MCCOY, D., MCGUIRE, B., MONTGOMERY, H., NAPIER, D., PAGEL, C., PATEL, J., DE OLIVEIRA, J.A.P., REDClifT, N., REES, H., ROGGER, D., SCOTT, J., STEPHENSON, J., TWIGG, J., WOLFF, J. \& PATTERSON, C. 2009. Managing the health effects of climate change. The Lancet, 373(9676):16931733, 16 May. Available athttp://www.thelancet.com/journals/lancet/article/PIIS0140-6736(09)60935$1 /$ fulltext

FRENCH, G., AWOSIKA, L. \& IBE, C. 1994. Sea-level rise in Nigeria: Potential impacts and Consequences, Journal of Coastal Research, 14:1-45, Special Issue.

HUNTER, L.M. \& DAVID, E. 2009. Climate change and migration: considering the gender dimensions. Institute of Behavioural Sciences. Boulder: University of Colorado. Population Program Working Paper Series (Draft). Available at http://www.colorado.edu/ibs/pubs/pop/pop2009-0013.pdf ICIMOD (International Centre for Integrated Mountain Development). 2009. Socio-cultural engagement and sensitivity in disaster risk reduction. Briefing Paper No. 1/09. Kathmandu: ICIMOD

JIGYASU, R. 2002. Reducing disaster vulnerability through local knowledge and capacity: the case of earthquake-prone rural communities in India and Nepal. Trondheim: Norwegian University of Science and Technology. (Thesis - Dr.Ing.)

JIGYASU, R. 2005. Disaster - a 'reality' or 'construct'? perspectives from the 'East'. (In Perry, R. \& Quarantelli, E., eds. What is a disaster? perspectives on the question”. 2nd ed. Xlibris.

KWARA STATE. 2010. About Kwara State. Available at: http://www.kwarastate.gov.ng/aboutkwara-state.html Date of access: 10 Feb. 2011.

MCGRANAHAN, G. 2007. Evolving urban health risks in low- and middle- income countries: from housing, water and sanitation to cities and climate change. Paper read at the Global Earth Summit, organized by the Center for Sustainable Urban Development held on July 15-20 in Bellagio, Italy. Available at: http://pubs.iied.org/pdfs/10553IIED.pdf

MUOGHALU, L. \& OKONKWO, A. 1998. Effects of urban flooding in Akwa, Anambra State of Nigeria. Environmental Review, 2:72-81

NPC (National Population Commission). 2009. 2006 Population and housing census of the Federal Republic of Nigeria. National and State Population and Housing Tables (Priority Tables) Vol. 1. Abuja: National Population Commission.

OLANIRAN, O. \& BABATOLU, J. 1996. Recent changes in rainfall pattern and its implications for flood occurrence in Ondo, Nigeria, Ondo Journal of Arts and Social Sciences 1:125-136. 
OLOGUNORISA, E. 1999. Flood hazard perception and adjustment in Ondo, Southwestern Nigeria, Journal of Nigerian Affairs, 4:172-193.

OREBIYI, A. 2002. Nigerian Red Cross Society 2001: Central Council Report. Lagos: Nigerian Red Cross.

ORIOLA, O. 1994. Strategies for combating urban flooding in a developing nation: a case study from Ondo. The Environmentalist, 14(1):57-62.

PALM, R.I. 1990. Natural hazards: an integrative framework for research and planning. Baltimore: Johns Hopkins University Press. 184 p.

UNDP (United Nations Development Programme). 2004. Reducing disaster risk: a challenge for development. New York: Bureau for Crisis Prevention and Recovery. Available at: http://www.undp. org/cpr/whats_new/rdr_english.pdf

WIKIMEDIA. 2011. Nigeria Kwara State Map. Available at: http://commons.wikimedia.org/wiki/ File:Nigeria_Kwara_State_map.png 